4-2009

\title{
Dan Freed: My Teacher, My Colleague, My Friend
}

Ronald Weich

Dean, University of Baltimore School of Law, rweich@ubalt.edu

Follow this and additional works at: http://scholarworks.law.ubalt.edu/all_fac

Part of the Criminal Law Commons, Criminal Procedure Commons, Legal Education Commons, and the Legal History Commons

\section{Recommended Citation}

Dan Freed: My Teacher, My Colleague, My Friend, 21 Fed. Sent. R. 248 (2009)

This Article is brought to you for free and open access by the Faculty Scholarship at ScholarWorks@University of Baltimore School of Law. It has been accepted for inclusion in All Faculty Scholarship by an authorized administrator of ScholarWorks@University of Baltimore School of Law. For more information, please contact snolan@ubalt.edu. 


\section{Dan Freed: My Teacher, My Colleague, My Friend}

At a recent meeting of the National Association of Sentencing Commissions, Yale professor Dan Freed was honored during a panel discussion titled "Standing on the Shoulders of Sentencing Giants." Dan Freed is indeed a sentencing giant, but he is the gentlest giant of all. It is hard to imagine that a man as mild-mannered, softspoken, and self-effacing as Dan Freed has had such a profound impact on federal sentencing law and so many other areas of criminal justice policy. Yet he has.

I've been in many rooms with Dan Freed over the years-classrooms, boardrooms, dining rooms, and others. Dan is usually a light and gentle participant, even in discussions he is leading. Yet time and again, he silences the gathering with his rare ability to synthesize arguments, convey important thoughts persuasively, and, above all, ask the right questions.

I first came to know Dan when I was a Yale Law School student in the early 1980 . I took several classes with Dan, including one titled "Sentencing Principles" and another titled "Sentencing Process." Most law schools do not offer any classes in sentencing, let alone two. So it speaks volumes about Dan that he chose to spend an entire semester talking to us about sentencing process. We spent months considering how a sentencing decision should be reached, the factors that should inform it, and the role of the defendant, the victim, and members of the public before, during, and after sentence has been imposed.

Dan Freed has always valued process. He believes in process because he knows that a fair, open, and reasoned process bestows credibility on any ultimate decision. That precept applies equally to the process by which a criminal sentence is imposed and the process by which criminal justice policy is formulated.

In his sentencing seminars and in other classes, Dan posed many questions to his students. In part this was Dan's polite version of the Socratic method, but more than that I think Dan genuinely wanted to learn from us. He believed his students had as much wisdom to offer as he did, and we strived to make it so. Those seminars were incredibly enjoyable and challenging; at the end of the class period we talked excitedly among ourselves and looked forward to the next session.
Despite his penchant for bow ties, Dan is not at all the abstract academic imagining worlds that do not exist. His title at Yale was professor of law and its administration. He had one foot in the courtyards of New Haven and the other firmly planted in the gritty world of urban criminal justice. Before he arrived at Yale, Dan had been a key criminal justice policy maker, and he brought us many hard-won practical lessons from his years in Washington.

For example, as a naîve student I thought the solution to prison overcrowding was to build more prisons. But Dan taught me a very important lesson that was later captured in a Kevin Costner movie: if you build it, they will come. In practice, legislatures will increase the length of sentences to fill available prison space, so adding cells is rarely the answer to overcrowding.

I also had a running friendly dispute with Dan over the issue of regional disparity in federal sentencing. It seemed to me that the punishment for federal crimes should be uniform across the country, from Brooklyn to South Dakota to San Francisco. But Dan understood that even in the federal system, there are different cultures in courthouses across the country, and it is unrealistic to think that central decision makers can completely extinguish the urge of practitioners to impose sentences that are perceived by their neighbors to be fair. Of course, mandatory sentencing laws sometimes make it impossible for judges to do that, but Dan had an appreciation for the role of practitioners in smoothing out the rough edges of a centralized system.

Dan's respect for the practice of criminal law led him to bring to our Yale sentencing seminars all manner of criminal justice practitioners. We spoke with defense lawyers, prosecutors, and many, many judges. We spoke with probation officers because Dan understood they are key actors in the system. And we heard from legislators because Dan understood that the outcome in every criminal case is shaped by the initial work of Congress and state legislatures. Those discussions with practitioners were richly informative and really propelled me on my own career in criminal justice.

I lost touch with Dan for a couple of years after I left Yale. I had been working in the Manhattan District Attorney's Office, often applying lessons I had learned in Dan's

Federal Sentencing Reporter, Vol. 21, No. 4, pp. 248-250, ISSN 1053-9867 electronic ISSN 1533-8363 (C) 2009 Vera Institute of Justice. All rights reserved. Please direct requests for permission to photocopy or reproduce article content through the University of California Press's Rights and Permissions website, http://www.ucpressjournals.com/reprintInfo.asp. DOI: 10.1525/fsr.2009.21.4.248. 
class. At some point I thought to reestablish contact with him but was a bit embarrassed that we had not spoken for some time and was not sure he would remember me. Of course he did.

Dan is a great mentor to his students, even years after they have left school. And he has a wonderful gift for putting people together. He'll say, "Well, have you spoken to so-and-so? Maybe that person will put you in touch with somebody else." Dan is a great networker, not for his own purposes but for the benefit of his students, and to the great benefit of the criminal justice field.

Soon after I reestablished contact with Dan, I told him I wanted to move beyond the important but retrospective work of prosecution. I wanted to work on policies that might prevent kids from joining the sad parade of dropouts and drug addicts in Manhattan Criminal Court. Dan put me in touch with, among others, Senator Kennedy's former counsel Ken Feinberg; Ken put me in touch with Steve Breyer, who was then on the First Circuit and the U.S. Sentencing Commission.

Eventually I found myself with an offer to work at the Commission, which at that time was a very troubled new agency. Dan was one of the Commission's leading critics, and when I asked what he thought of my potential career move, he said to me very sternly, "Well, if you were my son, I wouldn't allow you to do that." But I decided to do it over Dan's gentle objections, and he came to see that it was an interesting choice.

I arrived at the Commission at a fascinating and tumultuous time just after the Guidelines had become effective and were being challenged in courts across the country. Indeed, it was an interesting time in criminal justice generally - the era of Len Bias's overdose and the use of Willie Horton's furlough as an issue against presidential candidate Michael Dukakis. I immersed myself in the principles and the process of sentencing in those years and deepened my friendship with Dan as we shared insights, frustrations, and gossip about the tightly knit world of federal sentencing.

Dan had a complex relationship with the Sentencing Commission in its early years. He was one of the fathers of Federal Sentencing Guidelines, but his offspring was often in trouble. It was in court all the time! Dan walked a fine line because he still believed in the theory of guidelines, but these Federal Guidelines strayed far afield from the goals of the Sentencing Reform Act, which Dan generally considered a well-balanced piece of legislation.

Ironically, Dan was most frustrated with some of the academics on the early seven-member Commission, because they were, well, too academic for Dan. Instead he made common cause with judges, not just with thenJudge Breyer but with judges off the Commission who played an active role in the policy debates, like Jon Newman on the Second Circuit and Ed Becker on the Third Circuit.

Of course, it bothered Dan that the Commission lacked a satisfactory process. The original 1987 version of the
Guidelines had been written in back rooms, and even though Judge Breyer did a masterful job of putting a rational sheen on that product, it was a ragged piece of work in many ways. Through the years, commissioners would ask Dan to suggest improvements to the Guidelines, and he did so. But he would also suggest improvements to the process by which the Commission developed guidelines. If only more of his many suggestions had been adopted.

Even as a critic of the Sentencing Commission, Dan remained a believer in the need for a Commission. One of the duties imposed on the Commission in the Sentencing Reform Act is to "make recommendations to Congress concerning modification or enactment of statutes relating to sentencing, penal, and correctional matters that the Commission finds to be necessary and advisable to carry out an effective, humane and rational sentencing policy." If Dan did not write those words himself, he certainly inspired them, because they summarize Dan Freed's career.

I left the Commission in early 1989 and went to work in Congress, where Dan got his start working for Lyndon Johnson. But the congressional process had broken down badly in the twenty-five years between our tenure as staffers and has continued to deteriorate since then. Committee hearings and committee reports became exceptions rather than the rule. As I would talk to Dan about my work, he would always ask the right questions: Were the practitioners consulted? What did the public know about a piece of legislation before it came to a vote? Did Congress memorialize its intent?

As I worked in Congress, I stumbled upon Dan's earlier career. I knew him as a sentencing expert, but when I worked on a hearing about federal bail practices, I found out that Dan and his friend (future United States Court of Appeals for the District of Columbia Circuit Judge) Patricia Wald had played a critical role in the passage of early federal bail legislation in the 1960 . And when I worked on appointments to the District of Columbia Superior Court, I found out that Dan and Judge Harold Green had played a seminal role in the restructuring of the D.C. criminal courts, establishing the D.C. Superior Court, which is today one of the finest courts in the country with outstanding judges.

Dan worked on indigent defense issues. He worked on speedy trial issues in the 1960 s when he was in Bobby Kennedy's Justice Department. And he worked with some of the most brilliant and important figures in criminal justice before decamping to Yale Law School to escape the Nixon revolution in 1968 .

Later in my career, after leaving Capitol Hill for the first time, I came to know Dan in other capacities as well. He and Marc Miller had started the Federal Sentencing Reporter, and they persuaded me to write some early articles. Dan is a great editor. He is a graceful writer himself, but more importantly he knows how to organize ideas and in his engaging way he persuades an author to structure 
an argument so it can be more accessible and persuasive to the reader.

I also came to know Dan as a colleague on the Board of the Vera Institute of Justice. When Vera Director Chris Stone, who had been a classmate of mine in Dan's sen. tencing seminars, invited me to join the Board I leaped at the chance. It was fun to go up to the Vera board meetings in New York-there was always Chinese food for lunch because the offices were near Chinatown-where we would talk about Vera's projects, some of which Dan had been involved in for decades.

When Dan would speak at those meetings it was very much like the old E. F. Hutton commercial. We were basically a bunch of loud New Yorkers arguing and talking over each other, but when Dan cleared his throat a silence would fall over the room. Everybody would turn to Dan Freed because we knew that the words that would come out of his mouth would be pearls of wisdom. As often as not, he spoke about the process by which Vera carried out its very important work over those years.

Through Dan, I've met so many wonderful people, and I spoke to a few of them recently about him. Pat Wald recalled with great fondness the years before she became a D.C. Circuit judge, working with Dan on those early criminal justice policies. She spent some time at home raising her kids and saw Dan as her "man on the inside of the Justice Department" as they worked together to improve the quality of justice in America.

I asked Laurie Robinson-the former director of the American Bar Association's Criminal Justice Section, an assistant attorney general under Janet Reno in the 1990 s (and again now under Eric Holder), and later the chair of the Vera Board-about her impressions of Dan. She spoke of his "fertile, excited mind" and his "restless curiosity." I asked her when she first met Dan, and she could not remember. She said Dan is "like the Constitution-he's always been there."

And I met one other very important person in my life through my work with Dan. One of the first articles I wrote for the Federal Sentencing Reporter was about the inconsistency between mandatory minimum sentences and the Sentencing Guidelines. Shortly thereafter I found myself working for Senator Kennedy on the Judiciary Committee, and a woman who had founded an organization called Families Against Mandatory Minimums came to lobby me. Some years later, I married Julie Stewart.

Julie also speaks with great affection for Dan's "gentle ways and questioning mind." She says that when she first met Dan, she felt ill-prepared as a nonlawyer to speak to him about sentencing. But immediately he asked for her views, putting her at ease and honoring her with his respect.

So Julie and I both say thank you to Dan Freed. Thanks for bringing us together and for everything he has done for Families Against Mandatory Minimums, for the U.S. Sentencing Commission, for the U.S. Senate, and for the cause of justice in the years he has graced the criminal justice field with his warm presence.

\section{Notes}

* Ronald Weich currently serves as the Assistant Attorney General for Legislative Affairs in the United States Depart. ment of Justice. The views expressed herein, which were originally delivered in oral form at a meeting of the National Association of Sentencing Commissions on August 3, 2008, are solely those of the author.

128 U.S.C. $\$ 995(a)(20)$ 